\title{
The integration of computerised accounting in the accounting curriculum as an educational learning curve for students enter- ing the business world
}

\author{
Elmarie Papageorgiou \\ School of Accountancy, University of the Witwatersrand, Johannesburg, South Africa
}

\begin{abstract}
At universities, educating students on real-life practices is one of the key drivers in a changing academic environment. Academic institutions encourage the study of the learning environment and ensure that appropriate strategies are in place for educating students. A first-year Accounting I student stated the importance of computerised accounting: "Computerised accounting is used in the workplace and therefore using it in varsity grants students a view on how things will be after completion of their respective degrees." Accordingly, the purpose of this study was to empirically investigate the perceived acquisition of information technology (IT) knowledge and determine the skills required for students to convert the knowledge gained into actions, as a learning curve for accounting students entering the business world. The results indicated that students' knowledge of Accounting I increased with the integration of computerised Accounting in the Accounting I Curriculum.
\end{abstract}

KEYWORDS: Accounting, education, first-year accounting student, information technology, practical knowledge, real-life practices, skills, university

CATEGORIES: - Social and professional topics $\rightarrow$ Information technology education • Social and professional topics $\rightarrow$ Student assessment $\bullet$ Social and professional topics $\rightarrow$ Race and ethnicity $\bullet$ Social and professional topics $\rightarrow$ Gender $\bullet$ Social and professional topics $\rightarrow$ Computational thinking $\bullet$ Social and professional topics $\rightarrow$ Information Information systems education • Applied computing $\rightarrow$ Personal computers and PC applications • Applied computing $\rightarrow$ Education • Theory of computation $\rightarrow$ Theory of database privacy and security

\section{INTRODUCTION}

Over the last few decades the development of information technology (IT) has had a great impact on the vast majority of South Africans. Top management therefore needs to create clarity and to provide users with guidance on how to manage IT and how best to leverage technology. Chudasama et al. 1 confirm that the development of computers and the evolution of internet IT has had a positive impact worldwide, and that the internet is one of the most important sources of information for students in institutions, as well as being a popular medium for delivering education material. In support of this, Boyce [2] states that computer technology should not be seen as a passive addition to lectures since professional bodies and employer groups are increasingly urging that accounting students be equipped with a range of technology skills relevant to their discipline. McMahon et al. 3. highlight the need to embrace students' perspectives by planning to increase their use of computers and ensuring that all graduates are able to discover new technologies when

Email: elmarie.papageorgiou@wits.ac.za entering the business world. In a study by McMahon et al. [3, p. 306], the following quote was noted from a first-year student who responded to a questionnaire distributed among students at a United Kingdom university:

All students should be taught basic computer and word processing skills as part of their course. I am expected to use a computer but have never been shown how to do so.

Wadee 4] maintains that chartered accountants (CAs) play a role in shaping the future and continue to engage in areas of critical importance to the development of a fledging economy. Currently, although Accounting I students are exposed to accounting theory, there is a need to include computerised accounting in the syllabus thereby exposing these students to real-life accounting practices. However, Ballantine et al. [5] and Ballantine et al. [6] contest that students who are more computer literate could become frustrated covering material they are already familiar with, while those who are less computer literate could feel constantly disadvantaged by their peers. The perfect balance would be ideal, between the levels of computer literacy of students, but very difficult to establish and to implement uniformly across institutions. 
The purpose of the findings is to investigate whether the integration of computerised accounting in the Accounting I curriculum is beneficial for firstyear Accounting students studying for a Bachelor of Commerce degree in terms of acquiring computerised accounting knowledge related to real-life practice. The study also investigates whether students' use of IT knowledge and concepts increased, which would be relevant on entering the business world after completing their studies.

The study comprises the following three research questions:

1. How does the integration of a computerised accounting module into the Accounting I curriculum benefit students in order for them to acquire computerised accounting knowledge and skills that relate to real-life practice?

2. What are the characteristics of first-year Accounting students who recommend the inclusion of a computerised accounting module in the Accounting I curriculum?

3. To what extent does students' use of IT knowledge and skills increase following the integration of a computerised accounting module into the Accounting I curriculum?

\section{LITERATURE REVIEW}

Gray and Collison [7] state that one of the three broad areas of concern in Accounting education is the inappropriate preparation for future employment. Furthermore, Boyce et al. 8] conclude that Accounting students should be given opportunities to develop their abilities so as to, ultimately, be equipped to develop their own personal and collective positions on accounting issues. Willcoxson et al. [9, p. 68] state that:

professional accreditation of Accounting degrees of an Australian university has acted as an attractor for students and therefore as a driver for the integration of professional and generic skills in the Accounting curriculum.

However, according to De Lange et al. [10], studies in the United States still highlight graduates' lack of preparedness for an accounting career. Chudasama et al. 11 emphasize the challenges faced by professional bodies and course coordinators when designing accounting courses that address the diverse needs of students, the educational philosophy of the university and the changing dynamics of global businesses.

Over and above these challenges students complain about insufficient time to use the computer laboratories, limited computer access and the lack of communication between students and lecturers. Chudasama et al. 1] conclude that students need some kind of formal introduction to and education in IT in order to equip them with the skills they need to improve the quality of their careers when they enter the business world. McCourt Larres et al. [11, p. 99] recognised the:

importance of integrating computers onto the accounting curriculum, but had no clear consensus on precisely what set of abilities computer literacy actually represents.

Studies have recognised the importance of Accounting students' perceptions and expectations regarding the acquisition of practical accounting knowledge that relates to real-life practices. A study by Stainbank [12] provides important information on students' perceptions of the usefulness of an accounting project in acquiring accounting knowledge and professional skills that enabled students to take responsibility for their learning and assisted them to relate to real-life practices. Barac [13] emphasizes the perceptions of the knowledge and skill requirements of the entry-level trainee accountant receiving training in communication, analytical, interpersonal and computer skills. Furthermore, a study by Steenkamp et al. [14] defines factors influencing the success of first-year Accounting students confirming that students that had Accounting as a school subject and regularly attended lectures were significantly more successful than students that did not have Accounting as a Grade 12 subject and did not attend lectures regularly. Müller et al. [15] validate the profile of a successful first-year Accounting student by identifying this as a student that is motivated, not repeating any subjects, younger than 30 and manages his or her time effectively. Another study by Stainbank [16] affirms that working in teams has a positive effect on students' management and intellectual skills and Wessels [17] emphasizes the importance of students acquiring relevant IT skills through the integration of IT in professional subjects.

According to Scofield [18, if students are assigned to a group, each participant is likely to achieve positive interdependence, individual accountability and heterogeneous interactions to promote the common business task. In addition, Boyce 2] states that students can expand their abilities and skills and can generate alternative points of view for critical evaluation by the group. Saat et al. [19] conclude that social interaction during practical training makes a more significant impact on accounting students' reasoning ability than their task-focused ability. However, Yaghi et al. 20. warn that there is a lack of interaction between students with and without knowledge, thus reducing the amount of voluntarily shared information, may reduce student competitiveness among peers.

On the other hand, Stainbank [16] argues that Accounting students are often required to work in teams, and therefore acquiring intellectual, organisational, personal, interpersonal and communication skills is of the utmost importance. Fellers 21] states that, ultimately, lecturers must be aware of what knowledge, skills and abilities students need and how to best prepare them for real-life practices. Fellers explains how students can acquire skills when working in groups by linking each participant's performance to the performance of the other team members, by sharing and exchanging resources through face-to-face interaction, by taking responsibility for being individually accountable for their part of the project, and by interacting positively with each other. 
According to Roberts et al. 22, the benefits of group work among accounting students include increasing the understanding of the student experience of group work and learning in a group. In a study by Osunade et al. [23, new applications have given academics more opportunities to improve productivity through collaboration and knowledge sharing. Togo and McNamee 24] state that a computer project that enhances an accounting student's learning should ultimately translate into better performance for the accounting course.

Wessels [17] argues that the ability of students to convert their knowledge of IT concepts into IT competencies has not yet been fully applied in the real-world arena. Wessels concludes that students gain a number of critical information and communication technology (ICT) skills in using the computer facilities set up by the universities in a networked environment but lectures still have to give explanations about the skills involved and how to apply them to business organisations. According to Wessels, various ICT skills are covered by South African universities like, operating systems, internet tools, database software to name a few. Wessels also confirms that one of the weaknesses in the current situation in South Africa regarding the IT education of Accounting students is that IT is not sufficiently integrated with other professional subjects.

Baard et al. 25] suggest that students with no background in Accounting achieve lower marks than students who had Accounting as a subject at school, while Clarke and Finnie [26, p. 29] conclude that students who had English as a first language at school had greater access to technology due to the different cultural and educational background of English and non-English speakers, as the

non-English speaking subjects (who were

all Black Africans) exhibited a less positive

view of computers as a beneficial tool of man

and a higher fear of computer power.

Wessels [17 supports the urgency to integrate IT skills in the Accounting curriculum as he believes it will ensure that students acquire the relevant and critical IT skills necessary to be competent within the South African business environment. In another study, Wessels [27] suggests that ICT skills are key drivers to becoming a $\mathrm{CA}$ in a changing business environment, and that understanding and using IT is crucial to assure competence.

\section{RESEARCH METHODOLOGY}

The research study used a mixed method design that was both quantitative and qualitative in nature. Information on students' Grade 12 symbols for Mathematics, English, as first or additional language, and Accounting, if Accounting was a Grade 12 subject, were included in the study. The computerised accounting module forms part of the Accounting I course that is compulsory for Bachelor of Commerce degree students. This course has been evaluated and implemented according to the SAICA Competency Framework 28] to ensure that all aspects of the framework are covered in the curriculum. SAICA [29, p. 32] states in this regard that "Information and Information Technology competencies have become an integral part of virtually every task undertaken by CA candidates". The computerised accounting module consists of four 45-minute lecture periods per week over a period of two weeks and three 45 minute tutorial periods per week over a period of three weeks. The course material and the project were distributed to the students. In the lectures the lecturer provided students with a broad framework of computerised accounting paying particular attention to the concepts and principles taught in the Accounting curriculum. The students were informed and briefed in detail to complete a computerised project in their tutorial periods.

The objectives of the study were to determine whether or not students acquire knowledge and skills and to investigate whether students' use of IT knowledge and concepts increased, which would be relevant on entering the business world after completing their studies.

\section{RESULTS AND DISCUSSION}

\subsection{Design of the experiment}

The questionnaire consisted of four sections, Section 1; demographics of the students, Section 2; symbols of English, Mathematics and Accounting obtained in Grade 12 and Accounting I mark obtained for the full academic year at university, Section 3; a list of fifteen skills and Section 4; students to state their knowledge of computerised accounting before and after attending the computerised accounting lectures and completing the computerised accounting project. The fifteen skills included in the questionnaire were obtained from the International Education Standard (IES) 30 to gain knowledge from the respondents regarding developing and increasing technical skills and gaining business management skills. This Standard (IES) 30 prescribes the mix of skills (intellectual, technical, personal, interpersonal and organizational) that candidates require to qualify as professional accountants enabling them to function as competent professionals in an increasingly complex and demanding environment. In Section 4 students indicated their option on a scale of 'Excellent', 'Good', 'Average' and 'Poor' against each skill and knowledge gained. The raw data was collected electronically from the questionnaires and the SPSS statistical package was used to analyse the data. An Ethics Clearance Certificate was issued by the Ethics Committee of the academic institution validating and approving the empirical study.

The results address whether the integration of computerised accounting in the Accounting I curriculum is beneficial for first-year Accounting students in terms of acquiring computerised accounting knowledge related to real-life practice. The following aspects were investigated: students' perceptions of the use of an accounting package to assist in greater learning and indepth understanding of accounting, students' benefits 
Table 1: Knowledge of computerised accounting before \& after lectures and the computerised accounting project

\begin{tabular}{|l|c|c|c|c|c|c|c|c|}
\hline & $\mathrm{N}$ & Mean & Std. Dev. & Excellent & Good & Average & Poor & Total \\
\hline $\begin{array}{l}\text { Knowledge of computerised ac- } \\
\text { counting before the lectures } \\
\text { and the computerised accounting } \\
\text { project }\end{array}$ & 380 & 3.03 & .902 & $5.2 \%$ & $23.5 \%$ & $34.4 \%$ & $36.9 \%$ & $100.0 \%$ \\
\hline $\begin{array}{l}\text { Knowledge of computerised } \\
\text { accounting after the lectures } \\
\text { and the computerised accounting } \\
\text { project }\end{array}$ & 483 & 2.16 & .731 & $16.2 \%$ & $55.3 \%$ & $24.8 \%$ & $3.7 \%$ & $100.0 \%$ \\
\hline
\end{tabular}

before and after completing the computerised accounting project, and students' skills acquired as a result of engaging in the computerised project. The latter was also investigated in terms of gender, race, English as first language and Grade 12 marks of Mathematics and Accounting.

An electronic questionnaire was developed which 536 first-year Accounting I students were requested to complete after they had completed the computerised project and attended the computerised lectures. The number of questionnaires returned was 483 , giving a response rate of $90.1 \%$. Of the 483 first-year Accounting I students who participated, $51.8 \%$ were female. Furthermore, with regard to language, $49.1 \%$ of respondents confirmed that English was their first language, while 43.1\% identified English as their second language, $6.2 \%$ had English as their third language and, surprisingly, $1.2 \%$ indicated that English was their fourth language. This might be due to the fact that they are foreign students or that English was not offered at school level. Nearly $85 \%$ of the respondents had Accountancy as a subject in Grade 12 and $46 \%$ of the students had obtained an A symbol for Accountancy in that year. Nearly three-quarters of students $(72 \%)$ had obtained $\mathrm{A}$ and $\mathrm{B}$ symbols for English, despite more than half of the students (50.9\%) reporting that English was not their first language. $22 \%$ of students confirmed that they had taken a computer-related subject in Grade 12 .

An open-ended question in Section 4 of the questionnaire explored of how students were assisted in using an accounting package to learn and understand accounting better. The response rate to this openended question was $84.1 \%$, with students responding enthusiastically as it gave them an opportunity to state their opinions. The following quotes emphasise the type of computerised knowledge gained by students:

Because you get to do accounting practically and not manually which is what is done in the real world.

It makes accounting easier and faster.

More practical for real life.

Some students learn more by doing practical things.

It is computer based and young people enjoy using computers so it will be easier for them to quickly grasp some accounting terms and procedures.
It has helped me understand the world of accounting better.

The results shown in Table1 1 indicate the impact of the findings extrapolated from the data gathered on the students' knowledge of computerised accounting before and after completing the project and attending lectures. It was merely an intuitive measure by the students of how much knowledge they acquired by attending the computerised accounting lectures and completing the computerised project. A four-point scale was introduced with 1 indicating 'Excellent' and 4, 'Poor'. A mean of 3.03 was reported before the project in relation to a 2.16 mean afterwards. In addition, the standard deviation was smaller after completing the project, which confirmed that completing the project and attending the computerised accounting lectures improved students' knowledge and skills. Overall, the project enabled the students to increase their knowledge and to understand computerised accounting. In the words of a few students:

You got to be able to understand the basics of accounting as an information system before you can apply that knowledge to a computer system. Without prior knowledge, one wouldn't be able to maximise the benefits of the accounting package due to a lack of understanding.

It introduces us to how things are actually done in practice.

Because you get to do accounting practically and not manually which is what's done in the real world.

Makes us understand what a computerised accounting is so that when we get to our respectable fields of work, we can apply our knowledge.

It was also noted that the 'Poor' responses decreased by $90 \%$, the 'Excellent' responses increased by $64.5 \%$, and the 'Good' responses indicated a major shift from $2.5 \%$ to $55.3 \%$, thus confirming that, by completing the computerised accounting project, students improved their skills and knowledge and acquired knowledge related to real-life practices.

Table 2 indicates which skills students attending the computerised accounting lectures benefitted from, the three most valuable skills in rank order and the rank average order. A four-point scale was introduced with 1 indicating 'Excellent', 2 as 'Good', 3 as 'Average' and 
Table 2: Skills in rank order of the most valuable skills, mean and rank average

\begin{tabular}{|c|c|c|c|c|c|c|c|c|c|}
\hline \multirow{3}{*}{ Skill } & \multicolumn{2}{|c|}{ Benefit } & \multicolumn{6}{|c|}{ Value ranking } & \multirow{3}{*}{$\begin{array}{l}\text { Rank } \\
\text { average }\end{array}$} \\
\hline & \multirow[b]{2}{*}{ Mean } & \multirow[b]{2}{*}{ Std Dev } & \multicolumn{2}{|c|}{$\begin{array}{l}\text { Most valu- } \\
\text { able }\end{array}$} & \multicolumn{2}{|c|}{$\begin{array}{l}2 \text { nd most } \\
\text { valuable }\end{array}$} & \multicolumn{2}{|c|}{$\begin{array}{l}\text { 3rd most } \\
\text { valuable }\end{array}$} & \\
\hline & & & Freq & Rank & Freq & Rank & Freq & Rank & \\
\hline $\begin{array}{l}\text { encourage you to be an active par- } \\
\text { ticipant in a group }\end{array}$ & 1.76 & .725 & 34 & 5 & 56 & 1 & 45 & 2 & 2.7 \\
\hline $\begin{array}{l}\text { give you insight into practical busi- } \\
\text { ness operations }\end{array}$ & 1.78 & .731 & 32 & 7 & 26 & 10 & 35 & 4 & 7.0 \\
\hline $\begin{array}{l}\text { broaden your knowledge in informa- } \\
\text { tion technology }\end{array}$ & 1.89 & .721 & 29 & 8 & 41 & 3 & 29 & 9 & 6.7 \\
\hline develop the ability to organise data & 1.91 & .682 & 34 & 5 & 50 & 2 & 37 & 3 & 3.3 \\
\hline $\begin{array}{l}\text { help you to develop skills in inter- } \\
\text { preting and understanding data }\end{array}$ & 1.97 & .715 & 8 & 14 & 29 & 8 & 30 & 6 & 9.3 \\
\hline $\begin{array}{l}\text { interact with culturally and academ- } \\
\text { ically diverse people }\end{array}$ & 2.01 & .769 & 37 & 4 & 35 & 6 & 25 & 11 & 7.0 \\
\hline $\begin{array}{l}\text { encourage you to apply your knowl- } \\
\text { edge to new situations }\end{array}$ & 2.01 & .744 & 29 & 8 & 28 & 9 & 33 & 5 & 7.3 \\
\hline $\begin{array}{l}\text { help you to consolidate your prior } \\
\text { knowledge of the course }\end{array}$ & 2.02 & .771 & 3 & 15 & 5 & 15 & 11 & 15 & 15.0 \\
\hline $\begin{array}{l}\text { help you relate theory to real-life } \\
\text { practice }\end{array}$ & 2.04 & .719 & 73 & 1 & 18 & 13 & 22 & 13 & 9.0 \\
\hline $\begin{array}{l}\text { encourage you to further use infor- } \\
\text { mation technology in your studies }\end{array}$ & 2.06 & .784 & 48 & 3 & 38 & 4 & 23 & 12 & 6.3 \\
\hline $\begin{array}{l}\text { help you to integrate your under- } \\
\text { standing of the different compo- } \\
\text { nents of the course }\end{array}$ & 2.10 & .728 & 12 & 13 & 12 & 14 & 21 & 14 & 13.7 \\
\hline $\begin{array}{l}\text { develop your ability to summarise } \\
\text { the available information }\end{array}$ & 2.12 & .737 & 49 & 2 & 20 & 11 & 62 & 1 & 4.7 \\
\hline $\begin{array}{l}\text { teach you to integrate your knowl- } \\
\text { edge of the discipline }\end{array}$ & 2.12 & .732 & 13 & 12 & 19 & 12 & 26 & 10 & 11.3 \\
\hline $\begin{array}{l}\text { increase your motivation to study } \\
\text { the course }\end{array}$ & 2.17 & .905 & 22 & 10 & 34 & 7 & 30 & 6 & 7.7 \\
\hline $\begin{array}{l}\text { encourage you to take decisions with } \\
\text { incomplete information }\end{array}$ & 2.30 & .784 & 17 & 11 & 37 & 5 & 30 & 6 & 7.3 \\
\hline
\end{tabular}

4, 'Poor'. A mean score lower than 2.0 indicated that the majority of the respondents selected the 'Excellent' and 'Good' options. The five highest ranked skills as per the mean score of the benefit in Table 2 are:

1. 'encourage you to be an active participant in a group'

2. 'give you insight into practical business operations'

3. 'broaden your knowledge in information technology'

4. 'develop the ability to organise data', and

5. 'help you to develop skills in interpreting and understanding data'

These skills scored lower than 2.0; which indicates that students found the computerised accounting project beneficial and were able to integrate the accounting knowledge when using a variety of skills. The skill that was rated the lowest (2.30), 'encourage you to take decisions with incomplete information', indicated that the questionnaire was aimed at immature first-year students who did not yet have the ability to make decisions with incomplete information. The mean of the benefit scored respectively 1.76 and 2.01 in Table 2 indicate that students focused on group work (encourage you to be an active participant in a group) and cultural interactions (interact with culturally and academically diverse people) rather than pervasive skills. Students had to select the most, second-most and third-most valuable skill in the computerised accounting project. The most valuable skill students perceived as emanating from the computerised project was, 'help you relate theory to real-life practice'; the second most valuable skill was 'encourage you to be an active participant in a group'; and the third most valuable was 'develop your ability to summarise the available information'. It was noted that the 'group effect' was important for students: to be an active participant in the group scored the highest rank average for the three most valuable skills. In contrast, the most valuable skills, 'help you relate theory to real-life practice' and 'develop your ability to summarise the available information,' were not ranked among the highest ranked skills and had a mean score higher than two.

In completing the computerised accounting module, students confirmed that they had acquired various skills that are beneficial in relation to real-life practice. As per Table 3 each skill was tested for significance 
Table 3: Analysis of the significance of each skill versus gender, race, Accounting I mark, and symbols obtained in Grade 12 for Accounting, English and Mathematics

\begin{tabular}{|c|c|c|c|c|c|}
\hline \multicolumn{6}{|l|}{ Gender } \\
\hline Skill & $\mathbf{N}$ & $x^{2}$ & df & $p$-value & Cramer's V \\
\hline encourage you to be an active participant in a group & 483 & 17.201 & 3 & .001 & .189 \\
\hline give you insight into practical business operations & 483 & 7.068 & 3 & .070 & .121 \\
\hline broaden your knowledge in information technology & 483 & 14.780 & 3 & .002 & .175 \\
\hline develop the ability to organise data & 483 & 8.262 & 3 & .041 & .131 \\
\hline help you to develop skills in interpreting and understanding data & 483 & 15.745 & 3 & .001 & .181 \\
\hline interact with culturally and academically diverse people & 483 & 7.594 & 3 & .055 & .125 \\
\hline encourage you to apply your knowledge to new situations & 483 & 6.257 & 3 & .100 & .114 \\
\hline help you to consolidate your prior knowledge of the course & 483 & 4.529 & 3 & .210 & .097 \\
\hline help you relate theory to real-life practice & 483 & 7.601 & 3 & .055 & .125 \\
\hline encourage you to further use information technology in your studies & 483 & 9.738 & 3 & .021 & .142 \\
\hline $\begin{array}{l}\text { help you to integrate your understanding of the different components } \\
\text { of the course }\end{array}$ & 483 & 4.823 & 3 & .185 & .100 \\
\hline develop your ability to summarise the available information & 483 & 10.576 & 3 & .14 & .148 \\
\hline teach you to integrate your knowledge of the discipline & 483 & 5.033 & 3 & .169 & .102 \\
\hline increase your motivation to study the course & 483 & 15.275 & 3 & .002 & .178 \\
\hline encourage you to take decisions with incomplete information & 483 & 1.800 & 3 & .615 & .061 \\
\hline \multicolumn{6}{|l|}{ Race } \\
\hline Skill & $\mathbf{N}$ & $x^{2}$ & df & $p$-value & Cramer's V \\
\hline encourage you to be an active participant in a group & 483 & 23.639 & 9 & .005 & .128 \\
\hline give you insight into practical business operations & 483 & 13.346 & 9 & .148 & .096 \\
\hline broaden your knowledge in information technology & 483 & 32.234 & 9 & .000 & .149 \\
\hline develop the ability to organise data & 483 & 32.547 & 9 & .000 & .150 \\
\hline help you to develop skills in interpreting and understanding data & 483 & 38.893 & 9 & .000 & .164 \\
\hline interact with culturally and academically diverse people & 483 & 27.228 & 9 & .001 & .137 \\
\hline encourage you to apply your knowledge to new situations & 483 & 29.976 & 9 & .000 & .144 \\
\hline help you to consolidate your prior knowledge of the course & 483 & 21.617 & 9 & .010 & .122 \\
\hline help you relate theory to real-life practice & 483 & 27.544 & 9 & .001 & .138 \\
\hline encourage you to further use information technology in your studies & 483 & 46.448 & 9 & .000 & .179 \\
\hline $\begin{array}{l}\text { help you to integrate your understanding of the different components } \\
\text { of the course }\end{array}$ & 483 & 32.439 & 9 & .000 & .150 \\
\hline develop your ability to summarise the available information & 483 & 30.373 & 9 & .000 & .145 \\
\hline teach you to integrate your knowledge of the discipline & 483 & 18.200 & 9 & .033 & .112 \\
\hline increase your motivation to study the course & 483 & 53.069 & 9 & .000 & .191 \\
\hline encourage you to take decisions with incomplete information & 483 & 8.655 & 9 & .470 & .077 \\
\hline \multicolumn{6}{|l|}{ Accounting I mark } \\
\hline Skill & $\mathbf{N}$ & $x^{2}$ & df & $p$-value & Cramer's V \\
\hline encourage you to be an active participant in a group & 483 & 14.645 & 15 & .477 & .101 \\
\hline give you insight into practical business operations & 483 & 17.434 & 15 & .294 & .110 \\
\hline broaden your knowledge in information technology & 483 & 15.934 & 15 & .386 & .105 \\
\hline develop the ability to organise data & 483 & 10.376 & 15 & .795 & .085 \\
\hline help you to develop skills in interpreting and understanding & 483 & 9.902 & 15 & .826 & .083 \\
\hline interact with culturally and academically diverse people & 483 & 14.383 & 15 & .497 & .100 \\
\hline encourage you to apply your knowledge to new situations & 483 & 11.308 & 15 & .730 & .088 \\
\hline help you to consolidate your prior knowledge of the course & 483 & 15.136 & 15 & .442 & .102 \\
\hline help you relate theory to real-life practice & 483 & 13.870 & 15 & .535 & .098 \\
\hline encourage you to further use information technology in your studies & 483 & 17.552 & 15 & .287 & .110 \\
\hline $\begin{array}{l}\text { help you to integrate your understanding of the different components } \\
\text { of the course }\end{array}$ & 483 & 7.543 & 15 & .941 & .072 \\
\hline develop your ability to summarise the available information & 483 & 9.157 & 15 & .869 & .080 \\
\hline teach you to integrate your knowledge of the discipline & 483 & 9.330 & 15 & .960 & .080 \\
\hline increase your motivation to study the course & 483 & 14.932 & 15 & .456 & .102 \\
\hline encourage you to take decisions with incomplete infor & 483 & 12.509 & 15 & .640 & .093 \\
\hline
\end{tabular}




\section{Accounting symbol in Grade 12}

Skill

encourage you to be an active participant in a group

give you insight into practical business operations

broaden your knowledge in information technology

develop the ability to organise data

help you to develop skills in interpreting and understanding data

interact with culturally and academically diverse people

encourage you to apply your knowledge to new situations

help you to consolidate your prior knowledge of the course

help you relate theory to real-life practice

encourage you to further use information technology in your studies

help you to integrate your understanding of the different components

of the course

develop your ability to summarise the available information

teach you to integrate your knowledge of the discipline

increase your motivation to study the course

encourage you to take decisions with incomplete information

English symbol in Grade 12

\section{Skill}

encourage you to be an active participant in a group

give you insight into practical business operations

broaden your knowledge in information technology

develop the ability to organise data

help you to develop skills in interpreting and understanding data

interact with culturally and academically diverse people

encourage you to apply your knowledge to new situations

help you to consolidate your prior knowledge of the course

help you relate theory to real-life practice

encourage you to further use information technology in your studies

help you to integrate your understanding of the different components

of the course

develop your ability to summarise the available information

teach you to integrate your knowledge of the discipline

increase your motivation to study the course

encourage you to take decisions with incomplete information

\section{Mathematic symbol in $\mathrm{Gr}$}

\section{Skill}

encourage you to be an active participant in a group

give you insight into practical business operations

broaden your knowledge in information technology

develop the ability to organise data

help you to develop skills in interpreting and understanding data

interact with culturally and academically diverse people

encourage you to apply your knowledge to new situations

help you to consolidate your prior knowledge of the course

help you relate theory to real-life practice

encourage you to further use information technology in your studies

help you to integrate your understanding of the different components

of the course

develop your ability to summarise the available information

teach you to integrate your knowledge of the discipline

increase your motivation to study the course

encourage you to take decisions with incomplete information

\begin{tabular}{|c|c|c|c|c|}
\hline $\mathbf{N}$ & $x^{2}$ & $\mathbf{d f}$ & $p$-value & Cramer's V \\
\hline 405 & 8.208 & 9 & .513 & .076 \\
\hline 405 & 8.546 & 9 & .480 & .084 \\
\hline 405 & 7.906 & 9 & .544 & .081 \\
\hline 405 & 8.295 & 9 & .505 & .083 \\
\hline 405 & 8.442 & 9 & .490 & .083 \\
\hline 405 & 15.959 & 9 & .068 & .105 \\
\hline 405 & 9.803 & 9 & .367 & .090 \\
\hline 405 & 6.573 & 9 & .681 & .074 \\
\hline 405 & 12.714 & 9 & .176 & .094 \\
\hline 405 & 4.672 & 9 & .962 & .057 \\
\hline 405 & 9.529 & 9 & .390 & .089 \\
& & & & .044 \\
\hline 405 & 2.797 & 9 & .076 & .100 \\
\hline 405 & 12.173 & 9 & .204 & .067 \\
\hline 405 & 5.378 & 9 & .800 & .074 \\
\hline 405 & 6.598 & 9 & .679 & \\
\hline
\end{tabular}

\begin{tabular}{|c|c|c|c|c|}
\hline $\mathbf{N}$ & $x^{2}$ & $\mathbf{d f}$ & $p$-value & Cramer's V \\
\hline 483 & 8.070 & 9 & .527 & .130 \\
\hline 483 & 3.304 & 9 & .951 & .048 \\
\hline 483 & 4.514 & 9 & .874 & .056 \\
\hline 483 & 8.114 & 9 & .523 & .075 \\
\hline 483 & 8.142 & 9 & .520 & .075 \\
\hline 483 & 4.934 & 9 & .840 & .059 \\
\hline 483 & 9.106 & 9 & .428 & .080 \\
\hline 483 & 7.375 & 9.598 & .072 & \\
\hline 483 & 15.547 & 9 & .077 & .104 \\
\hline 483 & 7.401 & 9 & .595 & .072 \\
\hline 483 & 6.785 & 9 & .659 & .069 \\
& & & & \\
\hline 483 & 5.413 & 9 & .797 & .061 \\
\hline 483 & 4.455 & 9 & .879 & .056 \\
\hline 483 & 9.610 & 9 & .383 & .082 \\
\hline 483 & 4.053 & 9 & .908 & .053 \\
\hline
\end{tabular}

$483 \quad 4.053$

.908

.053

\begin{tabular}{|c|c|c|c|c|}
\hline $\mathbf{N}$ & $x^{2}$ & $\mathbf{d f}$ & $p$-value & Cramer's V \\
\hline 483 & 8.208 & 9 & .513 & .076 \\
\hline 483 & 15.802 & 9 & .071 & .105 \\
\hline 483 & 5.364 & 9 & .801 & .061 \\
\hline 483 & 2.797 & 9 & .972 & .044 \\
\hline 483 & 2.710 & 9 & .975 & .043 \\
\hline 483 & 15.959 & 9 & .068 & .105 \\
\hline 483 & 4.860 & 9 & .846 & .058 \\
\hline 483 & 7.669 & 9 & .568 & .073 \\
\hline 483 & 12.714 & 9 & .176 & .094 \\
\hline 483 & 4.672 & 9 & .862 & .057 \\
\hline 483 & 8.145 & 9 & .520 & .075 \\
& & & & .070 \\
\hline 483 & 7.057 & 9 & .631 & .068 \\
\hline 483 & 6.574 & 9 & .681 & .066 \\
\hline 483 & 6.277 & 9 & .712 & .049 \\
\hline 483 & 3.412 & 9 & .946 & \\
\hline
\end{tabular}


against gender, race, Accounting I mark and symbols obtained in Accounting, English and Mathematics in Grade 12. No significant associations were found between the fifteen skills and the Accounting I mark, and symbols obtained in Accounting, English and Mathematics. However, a chi-square test indicated that seven of the fifteen skills in relation to gender was also significant with $p<0.05$ and the relationship between skills and race was significant as twelve of the fifteen skills indicated $p<0.05$. In the listed skills the majority of the females selected the options 'Excellent' and 'Good' for each skill, except for the skill 'increase your motivation to study the course', which was selected by the majority of male students.

Students were further asked to state whether the inclusion of computerised accounting in the Accounting I curriculum had an influence on their academic performance. The findings confirmed a $27.7 \%$ failure rate for Accounting I after the first semester and comprises of: $5.8 \%$ recommended integrating computerised accounting into the Accounting I curriculum, 20.9\% recommended not including computerised accounting in the Accounting I curriculum and 1\% did not respond. However, $57.1 \%$ of the respondents that obtained $50 \%$ or more for Accounting I after the first semester confirmed that computerised accounting should be included in the Accounting I course. Results confirmed that the majority of students that had failed or passed Accounting I after the first semester agreed that the computerised accounting module should be included in the Accounting I course. Wessels [17 27 31 investigates to which extent students studying accountancy at South African universities need to acquire information and communication skills (ICT) skills to be competent in using information technology through the integration of IT in the Accounting curriculum. Wessels' findings [17 31] confirm the urgency to include computerised accounting and IT in the Accounting I curriculum, while his 2005 study 27 confirms that it could influence the academic performance of students.

Table 4 shows the results of the students' responses on the inclusion of the computerised accounting module in the Accounting I course on being tested for significance by gender, race, English as a first language or other, Accounting, Mathematics and English symbols in Grade 12, IT knowledge before and after the computerised accounting project, the Accounting mark and the skill with the highest frequency. Accordingly, no significant associations were found between the recommendation to integrate computerised accounting and these variables. As per Table 5 the Chi-square test did, however, indicate that the relationship between recommending integrating computerised accounting and symbols in Grade 12 for Mathematics, English as first language and Accounting was significant at $p<0.05$. The majority of students who obtained A and B symbols for Accounting and Mathematics in Grade 12 subject recommended that the computerised accounting module should be integrated into the Accounting I curriculum. In addition, the majority of students who obtained B and C symbols for English as first language in Grade 12 made the same recommendation. However, the majority of students who obtained an A symbol for English recommended that computerised accounting should not be integrated, which was contrary to the findings of Clarke and Finnie [26].

\section{CONCLUSION, RECOMMENDATIONS AND FUTURE RESEARCH}

The integration of the computerised accounting module into the Accounting I curriculum was prompted by students who had completed their studies, but had no or minimal computerised accounting experience and/or IT knowledge to apply in the business world. Accounting firms have also raised the fact that students need to equip themselves with IT skills in preparation for facing the business world. In this study, it was necessary to test not only the perceived acquisition of IT knowledge and skills, but also to consider whether students were able to convert the knowledge gained into practice. The purpose of the study was to investigate whether the integration of computerised accounting in the Accounting I curriculum was beneficial for firstyear Accounting students studying for a Bachelor of Commerce degree in terms of acquiring computerised accounting knowledge related to real-life practice. The study also investigated whether students' use of IT knowledge and concepts increased, which would be relevant on entering the business world after completing their studies.

The first research question was intended to establish how the integration of a computerised accounting module into the Accounting I curriculum might benefit students, in terms of acquiring computerised accounting knowledge and skills that relate to real-life practice. The students' responses, relating to the use of an accounting package to facilitate a better understanding of accounting, added value to the findings of the study. For example, one student noted:

I have learnt valuable information regard-

ing the Financial Statements as well as how accounting is practiced in the real world.

The findings showed that students' knowledge of computerised accounting increased, which confirms the findings of Stainbank 12 regarding the usefulness of such a project. The results also focused on the students' observations relating to the experience of group work. In conclusion, students rated the most valuable skill learnt as 'group participation'. This confirms the findings of Barac [13] in terms of the perception of knowledge and skill requirements and also confirms the positive effect of working in groups as reflected in the studies of Stainbank [16] and Roberts et al. [22].

The second research question determined the characteristics of first-year Accounting students who recommend the inclusion of a computerised accounting module in the Accounting I curriculum. Students who obtained A and B symbols for Accounting and Mathematics in Grade 12 subject recommended that the computerised accounting module should be integrated into the Accounting I curriculum. In addition, the 
Table 4: Response rate recommending the integration of the Computerised Accounting Module in the Accounting I course by gender; race; English as first language or other; Accounting, Mathematics and English symbols in Grade 12; IT knowledge before and after the Computerised Accounting Module; Accounting I mark

\begin{tabular}{|c|c|c|c|c|c|}
\hline $\begin{array}{l}\text { Responses recommending the integration of Computerised } \\
\text { Accounting Module in the Accounting I course }\end{array}$ & $\mathbf{N}$ & Yes & No & $\mathbf{N} / \mathbf{A}$ & Total \\
\hline Gender & 478 & & & & \\
\hline Male & & $54.9 \%$ & $44.6 \%$ & $0.5 \%$ & $100 \%$ \\
\hline Female & & $59.2 \%$ & $39.2 \%$ & $1.6 \%$ & $100 \%$ \\
\hline Race & 478 & & & & \\
\hline Asian & & $52.1 \%$ & $47.9 \%$ & - & $100 \%$ \\
\hline African & & $60.8 \%$ & $39.2 \%$ & - & $100 \%$ \\
\hline Coloured & & $53.8 \%$ & $46.2 \%$ & - & $100 \%$ \\
\hline White & & $56.5 \%$ & $43.5 \%$ & - & $100 \%$ \\
\hline English as a first language student & 478 & & & & \\
\hline Yes as first language & & $53.4 \%$ & $46.6 \%$ & - & $100 \%$ \\
\hline No as first language & & $61.9 \%$ & $38.1 \%$ & - & $100 \%$ \\
\hline Accounting Mark: Symbol & 400 & & & & \\
\hline A & & $50.0 \%$ & $50.0 \%$ & - & $100 \%$ \\
\hline B & & $61.6 \%$ & $38.2 \%$ & - & $100 \%$ \\
\hline $\mathrm{C}$ & & $73.3 \%$ & $26.7 \%$ & - & $100 \%$ \\
\hline $\mathrm{D}$ & & $80.0 \%$ & $20.0 \%$ & - & $100 \%$ \\
\hline Mathematics Mark: Symbol & 473 & & & & \\
\hline $\mathrm{A}$ & & $50.9 \%$ & $49.1 \%$ & - & $100 \%$ \\
\hline $\mathrm{B}$ & & $60.7 \%$ & $39.3 \%$ & - & $100 \%$ \\
\hline $\mathrm{C}$ & & $71.8 \%$ & $28.2 \%$ & - & $100 \%$ \\
\hline $\mathrm{D}$ & & $75.0 \%$ & $25.0 \%$ & - & $100 \%$ \\
\hline English Mark as first language subject: Symbol & 478 & & & & \\
\hline A & & $44.4 \%$ & $55.6 \%$ & - & $100 \%$ \\
\hline B & & $59.6 \%$ & $40.4 \%$ & - & $100 \%$ \\
\hline $\mathrm{C}$ & & $64.2 \%$ & $35.8 \%$ & - & $100 \%$ \\
\hline $\mathrm{D}$ & & $87.5 \%$ & $12.5 \%$ & - & $100 \%$ \\
\hline Skills and knowledge before the project & 475 & $57.9 \%$ & $42.1 \%$ & - & $100 \%$ \\
\hline Skills and knowledge after the project & 478 & $57.7 \%$ & $42.3 \%$ & - & $100 \%$ \\
\hline Accounting I Mark & 478 & & & & \\
\hline Fail & & $68.9 \%$ & $31.1 \%$ & - & $100 \%$ \\
\hline Pass & & $53.5 \%$ & $46.5 \%$ & - & $100 \%$ \\
\hline
\end{tabular}

Table 5: Recommendation to include the Computerised Accounting Module in the Accounting I course by gender; race; English as first language or other; Accounting, Mathematics and English symbols in Grade 12; IT knowledge before and after the Computerised Accounting Module; Accounting I mark: Chi-square test of independence

\begin{tabular}{|l|c|c|c|c|c|}
\hline $\begin{array}{l}\text { Responses recommending the integration of Computerised } \\
\text { Accounting Module in the Accounting I course }\end{array}$ & $\mathbf{N}$ & $x^{2}$ & $\mathbf{d f}$ & $p$-value & Cramer's V \\
\hline Gender & 478 & $1.023 *$ & 1 & .312 & $\mathrm{~N} / \mathrm{A}$ \\
\hline Race & 478 & 2.595 & 3 & .458 & $\mathrm{~N} / \mathrm{A}$ \\
\hline English as a first language student & 478 & $3.171 *$ & 1 & .075 & $\mathrm{~N} / \mathrm{A}$ \\
\hline Accounting Mark: Symbol & 400 & 12.534 & 3 & .006 & .177 \\
\hline Mathematics Mark: Symbol & 473 & 12.421 & 3 & .006 & .162 \\
\hline English Mark as first language subject: Symbol & 474 & 13.178 & 3 & .004 & .167 \\
\hline Skills and knowledge before the project & 475 & 6.409 & 3 & .093 & N/A \\
\hline Skills and knowledge after the project & 478 & 1.561 & 3 & .668 & N/A \\
\hline Accounting I Mark & 478 & 10.466 & 5 & .396 & N/A \\
\hline
\end{tabular}


majority of students who obtained B and $\mathrm{C}$ symbols for English as first language in Grade 12 made the same recommendation.

The findings produced by the third question established the viability of integrating computerised accounting into the Accounting I course. In conclusion, $75.2 \%$ of students confirmed that using an accounting package would assist them to learn and understand Accounting in terms of real-life practice, which will increase in using the IT knowledge and skills to be relevant when they enter the business world in three to four years' time.

It is recommended that the findings of this study be shared with other institutions that are considering integrating IT knowledge into their curriculum. The driving force behind the integration of computerised accounting into Accounting $\mathrm{I}$ is the belief that IT exposure, IT content and Accounting theory contribute to the success of Accounting I students and assist them to be competitive in a business accounting information environment.

Further research could be expanded at a local level where there is still tremendous scope for targeting Accounting students who have not been exposed to IT to compare similarities and differences of those students with and without IT knowledge. The expectation is that, over time, this study will provide a learning curve for students' knowledge and provide them with skills in acquiring practical accounting knowledge.

\section{REFERENCES}

[1] R. K. Chudasama, N. K. Godara and R. K. Srivastava. "Assessing computer literacy and attitude towards elearning among final year medical students." Internet Journal of Medical Informatics, vol. 5, no. 1, 2009.

[2] G. Boyce. "Computer-assisted teaching and learning in accounting: Pedagogy or product?" Journal of Accounting Education, vol. 17, no. 2, pp. 191-220, 1999.

[3] J. McMahon, J. Gardner, C. Gray and G. Mulhern. "Barriers to student computer usage: Staff and student perceptions". Journal of Computer Assisted Learning, vol. 15, no. 4, pp. 302-311, 1999.

[4] N. Wadee. "Influencing and shaping the future: The role of the profession". Accountancy SA, vol. 7, October 2011.

[5] J. A. Ballantine, P. McCourt Larres and P. Oyelere. "Computer usage and the validity of self-assessed computer competence among first-year business student self-assessed computer competence among first-year business students". Computers \& Education, vol. 49, no. 4, pp. 976-990, 2007.

[6] J. Ballantine and P. McCourt Larres. "Accounting undergraduates' perceptions of cooperative learning as a model for enhancing their interpersonal and communication skills to interface successfully with professional accountancy education and training". Accounting Education: an international journal, vol. 18, no. 4-5, pp. 387-402, 2009.

[7] R. Gray and D. Collison. "Can't see the wood for the trees, can't see the trees for the numbers? Accounting education, sustainability and the public interest".
Critical Perspectives on Accounting, vol. 13, no. 5, pp. 797-836, 2002.

[8] G. Boyce, S. Greer, B. Blair and C. Davids. "Expanding the horizons of accounting education: Incorporating social and critical perspectives". Accounting education, vol. 21, no. 1, pp. 47-74, 2012.

[9] L. Willcoxson, M. Wynder and G. K. Laing. "A wholeof-program approach to the development of generic and professional skills in a university accounting program". Accounting Education: an international journal, vol. 19, no. 1-2, pp. 65-91, 2010.

[10] P. De Lange, B. Jackling and A.-M. Gut. "Accounting graduates' perceptions of skills emphasis in undergraduate courses: An investigation from two Victorian universities". Accounting \& Finance, vol. 46, no. 3, pp. 365-386, 2006.

[11] P. McCourt Larres, J. Ballantine and M. Whittington. "Evaluating the validity of self-assessment: Measuring computer literacy among entry-level undergraduates within accounting degree programmes at two UK universities". Accounting Education, vol. 12, no. 2, pp. 97-112, 2003.

[12] L. Stainbank. "Students' perceptions of the usefulness of an accounting project in acquiring accounting knowledge and professional skills". South African Journal of Accounting Research, vol. 24, no. 1, pp. 79-100, 2010.

[13] K. Barac. "South African training officers' perceptions of the knowledge and skills requirements of entry-level trainee accountants". Meditari Accountancy Research, vol. 17, no. 2, pp. 19-46, 2009.

[14] L. Steenkamp, R. Baard and B. Frick. "Factors influencing success in first-year accounting at a South African university: A comparison between lecturers' assumptions and students' perceptions". SA Journal of Accounting Research Vol, vol. 23, no. 1, pp. 113-140, 2009.

[15] H. Müller, P. Prinsloo and A. Du Plessis. "Validating the profile of a successful first year accounting student". Meditari Accountancy Research, vol. 15, no. 1, pp. 1933, 2007.

[16] L. Stainbank. "Working in teams: An examination of the variables that improve team performance in accounting students". South African Journal of Accounting Research, vol. 19, no. 1, pp. 103-111, 2005.

[17] P. Wessels. "The identification and discussion of strategies for implementing an IT skills framework in the education of professional accountants". South African Journal of Accounting Research, vol. 22, no. 1, pp. 147-181, 2008.

[18] B. W. Scofield. "Adapting cases for a team approach". Journal of Accounting Education, vol. 23, no. 4, pp. 248-263, 2005.

[19] M. Mohamed Saat, S. Porter and G. Woodbine. "A longitudinal study of accounting students' ethical judgement making ability". Accounting Education, vol. 21, no. 3, pp. 215-229, 2012.

[20] K. Yaghi, S. Barakat, Z. M. Alfawaer, M. Shkokani and A. Nassuora. "Knowledge sharing degree among the undergraduate students: A case study at Applied Science Private University". International Journal of Academic Research, vol. 3, no. 1, 2011. 
[21] J. W. Fellers. "People skills: Using the cooperative learning model to teach students 'people skills"'. Interfaces, vol. 26, no. 5, pp. 42-49, 1996.

[22] M. Roberts, J. Parker, J. Joyce and T. Hassall. "Improving group work in accounting: A student perspective". In Teaching Learning $\&$ Assessment conference. 2007.

[23] O. Osunade, O. Philips and O. Ojo. "Limitations of knowledge sharing in academia: A case from Nigeria". Knowledge Management for Development Journal, vol. 3, no. 1, pp. 26-34, 2007.

[24] D. F. Togo and A. H. McNamee. "Computer integration into the accounting curriculum: Learning benefits, problems, and guidelines". Journal of Accounting Education, vol. 13, no. 2, pp. 149-158, 1995.

[25] R. Baard, L. Steenkamp, B. Frick and M. Kidd. "Factors influencing success in first-year accounting at a South African university: The profile of a successful first-year accounting student". SA Journal of Accounting Research Vol, vol. 24, no. 1, pp. 129-147, 2010.

[26] M. Clarke and G. Finnie. "Changes in entry-level university students' attitudes to computers from 1985 to 1997". South African Computer Journal, pp. 26-33, 1998.

[27] P. Wessels. "Critical information and communication technology (ICT) skills for professional accountants". Meditari accountancy research, vol. 13, no. 1, pp. 87103, 2005.

[28] South African Institute of Chartered Accountants. Competency framework detailed guidance for academic programmes: Competencies of a $C A(S A)$ at the point of the Part I examination. SAICA, 2010a.

[29] South African Institute of Chartered Accountants. Competency framework: Competencies of a chartered accountant (SA) at entry point to the profession. Johannesburg: SAICA, 2010.

[30] "International education standard (IES) 3Professional skills and general education", n.d. URL http://www.ifac.org/sites/default/ files/publications/files/ies-3-professionalskills.pdf

[31] P. Wessels. "An analysis of the current IT education offered to accounting students at South African universities". South African Journal of Accounting Research, vol. 21, no. 1, pp. 103-127, 2007. 